\title{
Parotid Gland Superficial Lobe
}

National Cancer Institute

\section{Source}

National Cancer Institute. Parotid Gland Superficial Lobe. NCI Thesaurus. Code C160992.

The portion of the parotid gland that is superficial to the facial vein and facial nerve. 